\title{
AN EXPLORATORY RESEARCH ON RELATIONSHIPS WITH STAKEHOLDERS IN INNOVATION
}

\author{
Rodica Boier \\ “Gh Asachi” Technical University of Iaşi \\ Rodica_Boier@yahoo.com
}

\begin{abstract}
High levels of product innovation activity are occurring through key companies leading and developing stakeholders networks. Thus, an innovating company will be always interested to know the degree to which component suppliers are willing to form partnerships by participating in its new products development process. Recognized as an effective opportunity for innovation, value co-creation allows the company to use relationships with customers and other stakeholders during the generating process, to create a space for mutual learning, cocreation and co-design, in which the stakeolders become an integrated part of the innovation and design process not only as a simple informants. The objective of the study was to describe the way that companies follow in their efforts to innovate involving the stakeholders. Relationships initiated, developed and maintained in this respect were studied on three Romanian companies that activate in the design and development of Enterprise Resource Planning (ERP) software solutions. They also deliver consultancy, implementation and postimplementation services for the products they sell. As source of information were used discutions conducted with directors of marketing from the three companies and also with several stakeholders involved in the innovation processes. Several similarities was found and described, for relationships specific to each category of stakeholder.
\end{abstract}

\section{Keywords}

innovation; new product development; relationship marketing; value co-creation; stakeholders

\section{JEL Classification}

M31

\section{Introduction}

In the innovation processes, the relationship marketing is applied in a diversity of contexts, each of them with their corresponding particularities. These differences come from the product type - its business-to-business or business-to-consumer settings -, the specific industry, the actual stage of the market evolution - emerging or mature -, the level of technological novelty as dimension of technological uncertainty, the position/ status and role of stakeholders as part in the relationships, the state of the new product development process in which the interactions occurs or special issues like sustainable innovation, for profit and not-for-profit areas etc. (Alam, 2012; Atahaide and Rochard, 2009; Bhalla, 2011, Bonner, 2010; Carbonell et al., 2009; Franke, 2006; Füller et al., 2011; Grönroos, 2011; Gustafsson et al., 2012; Hoyer et al., 2010; Ind and Coates, 2013; Kuusisto and Riepula, 2011; Lagrosen, 2005; Lambert, 2011; Lau, 2011; Lehtimäki et al., 2012; Lynch and O’Toole, 2010; Nambisan, 2009; Piller et al. 2011; Rust et al. 2010; Sofianti et al. 2010; Tanev et al., 2011; Zacharias, 2011).

Interaction management in customer integrated innovation is an opportunity for companies to supply relational service to customer and to improve customer value and relationship quality (Sun et al., 2010). But companies also try to understand how 
to ensure the best relational environment so that to provide the best sourcing of ideas from outside the company and even outside the industry, insights and knowledge from customers and end users, suppliers and competitors, universities, independent entrepreneurs, investors, inventors, scientists a.s.o.

For the organizations developing new products it is particularly challenging to understand customer needs which drive significant product innovation. Thus, it is important to identify the dimensions of the customer interaction process which lead to more proactive organizations. In a business-to-business setting, customer interactivity is conceptualized as a multi-dimensional construct consisting of bidirectional communications, participation, and joint problem solving with stakeholders during the projects of new product development. High levels of product innovation activity are occurring through key companies leading and developing stakeholders networks.

More and more often seller and a buyer enter into a relationship to mutually undertake the development of an innovative product. The new product development relationships generate a „cooperative competency” (Sivadas and Dwyer, 2000) and involve the product co-design, product co-development, joint problem solving a.o. In this context, a strong chapter of the relationship marketing regards the interactions between sellers and buyers during the new product development process when customizing the products. Thus, an innovating company will be always interested to know the degree to which component suppliers are willing to form partnerships by participating in its new products development process. Three key areas of positive influences on supplier intention for early supplier involvement are found by LaBahn and Krapfel (2000) as being the customer's exchange behavior, the structure of dependence in a relationship, and the technology factors.

Recognized as an effective opportunity for innovation, value co-creation allows the company to use relationships with customers and other stakeholders during the generating process, to create a space for mutual learning, co-creation and co-design, in which the stakeolders become an integrated part of the innovation and design process not only as a simple informants.

\section{Three case studies}

The objective of the study was to describe the way that companies follow in their efforts to develop new products involving the stakeholders. Relationships initiated, developed and maintained in this respect were observed on three Romanian companies that activate in the design and development of Enterprise Resource Planning (ERP) software solutions. They also deliver consultancy, implementation and post-implementation services for the products they sell. The source of information were the discutions conducted with directors of marketing from the three companies and also with several stakeholders involved in the innovation processes. Several similarities was found, as described in the following ideas.

These specific companies were choosen for the study on the basis of their product portfolios, being in a constant and dynamic evolution. For instance, a new product was launched on the market at every approximativelly 5 years. The main benefits brought to the customers consistes in an easy and fast access to the accounting and management information, freedom to run on under different operating systems, and the interconnectivity of modules and connectivity with peripheral devices used in accounting management. Step by step, new products resulted from the diversification of the core product, and this evolution required constant adjustment to different use environments. Accumulating a rich history of experience and cooperation, the companies have constantly increased its value through the rapid implementation of 
the requirements and ideas coming from the diverse range of customers, collaborators and partners. The product has had a constant upgrading thus there appeared many improved versions of the core product.

In support of this effort to innovate new products, an extensive and constantly active innovation relationship network was set up, a real engine that enabled the permanent improvement of the system. The innovation network management has relied in its specific interactions on the essential principles of relationship marketing, i.e. involvement, trust-based relationship and constant communication among partners, long-term customer satisfaction. In all of these three case studies, the partnership is made up of the huge number of individual end users, companies, authorized distributors, and other partners such as professional associations, colleges and universities with programs of study in the field.

The three companies surveyed considered their customers to simultaneously play different roles in relation to the new product - executive managers and top managers, the distributors, computer operators and IT specialists. For each of these categories, special relationship marketing actions where developed and implemented. The customer's executive managers who operate especially the outputs, the product reports and analysis areas, are a key partner in the innovation relationship network. Their involvement occurs at different stages of the process: in the pre-analysis and analysis stage, where the product can be adjusted to specific needs, then, through checks and tests performed by employees. They are less involved in the postimplementation phase, especially if the provision with solutions, reports etc. has reached its maturity. An increased relationship networking with the managers is once again achieved when the business growth is accompanied by an upgrading of the application configuration additional users, additional necessary modules etc.). The cycle is resumed with their involvement in pre-assessment, analysis and implementation assessment. On the other hand, since the customer as buyer expects to benefit from a more effective and efficient product, the relationship networking with top managers focuses strictly on the level of satisfaction or, in certain cases, dissatisfaction on the matter.

The value chain also includes the distributors who are involved throughout the entire process of innovation, in a complex and continuous relational system. Because of their status as "value added services providers", rather than just customers, the innovating companies considers them as business partners, who act like a real, active and effective interface with final customers. Consequently, the added value allocated to them was dimensioned so that to keep them motivated to build, maintain and develop the appropriate relationships with the customer, including in the postimplementation stage. The distributors' trust was further consolidated through their active involvement in the front-end stages, when the attention focuses on how to stimulate the input flow that represents the customers' requirements, the inputs translation into technical language, the joint analysis/ assessment of the necessary and possible solutions, the making of improvements, tests and implementation at the customer's location. It is interesting, and demonstrated by experience, that the satisfaction of this type of active involvement exceeds in many cases the strict financial satisfaction.The relationships established carefully gave the distributors the feeling of belonging to a family that is solid, cohesive, reliable, competitive, innovation-driven, that is at the forefront of trends both in technology and performance marketing practice.

The customer's computer operators, on the other hand, are involved in the current operational phase. The experience accumulated from the relationship with the computer operators proved that reactions to change may range from inertia to hostility 
or even violent rejection in some instances. Regardless of their nature - be they 'pro' or 'against' - the company was interested in gathering the reactions either directly from their supporters or indirectly from the client representatives of the companies' authorized dealers who maintain the customer relationships. The management of the customer relationship means to collect, analyze, respond and give the adequate solution to customer feedback by approaching each situation either directly or indirectly.

The IT specialists, are always in the "front line" of ERP system implementation. They detect and send the problems in real time. They are particularly valuable in the relationship as they do not create technical communication barriers, they can correctly describe the IT processes and have an adequate understanding of possible solutions. Their involvement is direct both in the implementation and post-implementation phases in that they provide the interface for support. They detect, localize and report the 'bugs', receive debugged versions, check them in actual use and confirm their correction, provide application architecture solutions, hardware/software solutions that are better adjusted to the actual use of the application.

Last but not least, an important actor in the innovation relationship network of the company is represented by the related professional associations. They offered valuable ideas on several aspects such as the improvement of product architecture, interface ergonomics, compliance to legislation, adjustments to the unprecedented turbulence in the Romanian financial-accounting legislation in the transition and post transition period etc. Good relationships developed and maintained with the professional associations were sustained through sponsorship and promotional pricing practices, or substantial discounts from price list offered to members.

Since the commercial success of a new product depends heavily on the compatibility between product and consumer, the innovating companies hadopted a proactive attitude by getting involved in the education of the prospective users. Product use rights for WM and WME were given to universities and high schools programmes in accounting and management information. Accommodating future users with a specific application during their school years creates a beneficial, solid information chain with favourable long-term outcomes. Support in installation and maintenance and training of lecturers was provided. The essential issue in this relationship was to monitor the transmission of accurate and complete information on the product, on its extensive use, near the full of its capacity. Careful selection of instructors with the appropriate expertise was crucial to the success of building and maintaining the relationship.

On a continuous basis, the flkow of new ideas for innovative solutions were gathered, discussed, analyzed and jointly tested, all along of these processes.

\section{References}

Alam, M.R. (2012), Relationship Marketing: perspectives and implications, International Journal of Business Economics\&Management Research, 2(3), 195-199.

Atahaide, G.A., Rochard R.K. (2009), Managing Seller-Buyer Relationships during New Product Development, Journal of Product Innovation Management, 26, 566-577.

Bhalla, G. (2011), Collaboration and Co-creation: New Platforms for Marketing and Innovation, Springer Science+Business Media, LLC, New York. 
Bonner, J.M. (2010), Customer interactivity and new product performance: Moderating effects of product newness and product embeddedness, Industrial Marketing Management, 39(3), 485-492.

Carbonell, P., Rodríguez-Escudero, A.I., Pujari, D. (2009), Customer Involvement in New Service Development: An Examination of Antecedents and Outcomes, Journal of Product Innovation Management, 26(5), 536-550.

Franke, N. (2006), Finding Commercially Attractive User Innovations: A Test of Lead-User Theory, Journal of Product Innovation Management, 23(4), 301315.

Füller, J., Hutter, K., Faullant, R. (2011), Why Co-Creation Experience matters? Creative Experience and its Impact on the Quantity and Quality of Creative Contributions, R\&D Management, 41(3), 259-273.

Grönroos, C. (2011), A service perspective on business relationships: The value creation, interaction and marketing interface, Industrial Marketing Management, 40(2), 240-247.

Gustafsson, A., Kristensson, P., Wittel, L. (2012), Customer co-creation in service innovation: a matter of communication?, Journal of Service Management, 23(3), 311-327.

Hoyer, W.D., Chandy, R., Dorotic, M., Krafft, M., Singh, S.S. (2010), Consumer Cocreation in New Product Development, Journal of Service Research, 13(3), 283-296.

Ind, N., Coates, N. (2013), The meanings of co-creation, European Business Review, 25(1), 86-95.

Kuusisto, A., Riepula, M. (2011), Customer interaction in service innovation: seldom intensive but often decisive. Case studies in three business service sectors, International Journal of Technology Management, 55(1/2), 171-186.

LaBahn, D.W., Krapfel, R. (2000), Early Supplier Involvement in Customer New Product Development: A Contingency Model of Component Supplier Intentions, Journal of Business Research, 47, 173-190.

Lagrosen, S. (2005), Customer involvement in new product development: A relationship marketing perspective, European Journal of Innovation Management, 8(4), $424-436$.

Lambert, D.M. (2011), Measuring value in co-creation in business-to-business Relationships, Otago Forum, 3, 99-127.

Lau, A. K.W. (2011), Supplier and customer involvement on new product performance: Contextual factors and an empirical test from manufacturer perspective, Industrial Management \& Data Systems, 111(6), 910 - 942.

Lehtimäki, T., Pääkkönen, T., Oinonen, M., Ojansivu, I., Salo, J. (2012), Industrial co-innovation process: relational approach, The XXIII ISPIM Conference Action for Innovation: Innovating from Experience, 17-20 June, Barcelona, Spania.

Lynch, P., O’Toole, T. (2010), A Critical Episode Analysis of the Dynamics of the Interaction Atmosphere in a New Product Development Relationship, The Industrial Marketing and Purchasing Journal, 4(2), 106- 130.

Nambisan, S. (2009), Virtual Customer Environments: IT-Enabled Customer Coinnovation and Value Co-creation, in Nambisan, S. (Ed.), Information technology and product development, Annals of information systems, 5(2), 109-127.

Piller, F., Ihl, C., Vossen, A. (2011), Customer Co-Creation: Open Innovation with Customers, in Wittke, W., Hanekop, H (Ed.), New Forms of Collaborative 
Innovation and Production on the Internet. An Interdisciplinary Perspective, Universitätsverlag Göttingen, 31-62.

Rust, R.T., Moorman, C., Bhalla, G. (2010), Rethinking Marketing, Harvard Business Review, 88(1), 94-101.

Sivadas, E., Dwyer, F.R. (2000), An Examination of Organizational Factors Influencing New Product Success in Internal and Alliance-Based Processes, Journal of Marketing, 64(1), 31-49.

Sofianti, T.D., Suryadi, K., Govindaraju, R., Prihartono, B. (2010), Customer Knowledge Co-creation Process in New Product Development, in Proceedings of the World Congress on Engineering 2010, Vol. I, June 30- July 2, London, U.K.

Sun, H., Yau, H.K., MingSuen, E.K. (2010), The Simultaneous Impact of Supplier and Customer Involvement on New Product Performance, Journal of Technology Management \& Innovation, 5(4), 70-82.

Tanev, S., Ruskov, P., Georgiev, L., Bailetti, T. (2011), A Business Intelligence Tool for Studying Value Co-creation and Innovation, Information technologies and control, 1, 2-9.

Zacharias, N. (2011), An Integrative Approach to Innovation Management Patterns of Companies' Innovation Orientation and Customer Responses to Product Program Innovativeness, Gabler Verlag, Springer Fachmedien, Heidelberg. 